AGRITECH, Vol. 37, No. 1, Februari 2017, Hal. 95-100 DOI: http://dx.doi.org/10.22146/agritech.17014 ISSN 0216-0455 (Print), ISSN 2527-3825 (Online) Tersedia online di https://jurnal.ugm.ac.id/agritech/

\title{
Karakterisasi Bakteri Asam Laktat Amilolitik dari Industri Pengolahan Pati Sagu
}

\author{
Characterization of Amylolytic Lactic Acid Bacteria from Sago Starch Processing Industry \\ Y. Yusmarini, Usman Pato, Vonny Setiaries Johan, Akhyar Ali, K. Kusumaningrum \\ Program Studi Teknologi Hasil Pertanian, Fakultas Pertanian, Universitas Riau, \\ Kampus Bina Widya Km. 12,5 Simpang Baru, Pekanbaru 28293, Indonesia \\ Email: marini_thp@yahoo.co.id
}

Submisi: 10 September 2015; Penerimaan: 26 Februari 2016

\begin{abstract}
ABSTRAK
Bakteri asam laktat (BAL) yang bersifat amilolitik adalah bakteri asam laktat yang mampu memanfaatkan pati sebagai substratnya. Tujuan penelitian adalah untuk mengkarakterisasi sifat amilolitik dan mengidentifikasi bakteri asam laktat yang mempunyai kemampuan amilolitik untuk memodifikasi pati sagu. Hasil penelitian memperoleh 39 isolat dari industri pengolahan sagu dan 36 diantaranya diduga sebagai bakteri asam laktat. Sembilan dari 36 isolat yang diduga bakteri asam laktat mempunyai sifat amilolitik. Sembilan isolat yang bersifat amilolitik selanjutnya diidentifikasi secara morfologi yang meliputi pewarnaan Gram, bentuk sel, uji katalase, dan uji kemampuan fermentasi. Hasil identifikasi secara morfologi menunjukkan bahwa kesembilan isolat termasuk kelompok bakteri Gram positif, katalase negatif, bentuk basil, dan lima isolat menghasilkan gas sedangkan empat isolat tidak menghasilkan gas. Kemampuan isolat untuk menghasilkan amilase bervariasi dan isolat RN2.12112 mempunyai kemampuan amilolitik lebih tinggi dibanding isolat lainnya. Hasil identifikasi menunjukkan bahwa dari sembilan isolat yang diidentifikasi didominasi oleh Lactobacillus plantarum 1.
\end{abstract}

Kata kunci: Karakterisasi; bakteri asam laktat; aktivitas amilolitik

\begin{abstract}
Amylolytic lactic acid bacteria are a group of bacteria that are capable to use starch as the carbon source. The objectives of this research were to characterize, and identify the lactic acid bacteria from sago starch processing industry, which might be used to modify the sago starch. There were 39 isolates isolated from sago processing industry, and 36 of them were presumed as lactic acid bacteria. From 36 isolates suspected as lactic acid bacteria, 9 of them had amylolytic properties. Morphological identification results show that the 9 isolates were 1 Gram-positive bacteria, negative catalase, rod shape, and 5 isolates produced gas, while 4 isolates did not produce gas. The ability to produce amylase varied among isolates and isolate RN2.12112 had the higher amylolytic ability than others. Results show that the nine isolates identified as lactic acid bacteria were dominated by Lactobacillus plantarum 1.
\end{abstract}

Keywords: Characterize; lactic acid bacteria; amylolytic activity 


\section{PENDAHULUAN}

Bakteri asam laktat (BAL) yang bersifat amilolitik adalah bakteri asam laktat yang mampu memanfaatkan pati sebagai substratnya. Beberapa BAL dapat menghasilkan amilase ekstraseluler dan memfermentasi pati secara langsung menjadi asam laktat. Isolasi dan identifikasi bakteri asam laktat yang bersifat amilolitik telah banyak dilakukan diantaranya dilakukan oleh Agati dkk. (1998) yang mengisolasi BAL dari produk fermentasi jagung, Songré-Ouattara dkk. (2008) telah mengisolasi BAL dari produk fermentasi berbasis cassava di Afrika dan Putri dkk. (2012) mengisolasi BAL dari growol. Isolat BAL yang telah diisolasi sebelumnya umumnya dari genus Lactobacillus.

Modifikasi pati dilakukan sebagai upaya untukmengubah sifat fisik dan kimia dari pati alami. Kesulitan atau kendala dalam penggunaan pati alami adalah selain menggunakan waktu yang lama saat pemasakan, pasta yang terbentuk juga cukup keras. Terjadinya retrogradasi dan sineresis pada pati alami juga menjadi kelemahan dari pati tersebut. Untuk memperluas penggunaan pati sagu yang ketersediaannya melimpah di Provinsi Riau dan untuk mendukung program diversifikasi pangan, pati sagu dapat dimodifikasi sehingga diperoleh pati sagu yang memiliki sifat reologi yang lebih baik. Modifikasi pati dapat dilakukan dengan cara pemotongan struktur molekul, penyusunan kembali struktur molekul, oksidasi atau dengan cara melakukan substitusi gugus kimia pada molekul pati. Terdapat beberapa metode modifikasi diantaranya modifikasi secara mikrobiologis dengan memanfaatkan bakteri asam laktat.

Beberapa peneliti telah melakukan penelitian modifikasi pati dengan memanfaatkan bakteri asam laktat. Armanto dan Nurasih (2008) menggunakan L. plantarum dalam membuat pati singkong asam yang biasanya digunakan untuk membuat roti, cake dan makanan ringan. Jenie dkk. (2012) menggunakan kultur campuran antara L. plantarum kik dan L. fermentum 2B4 dalam memodifikasi pati pisang tanduk. Sinaga (2012) memanfaatkan bakteri asam laktat yang biasanya digunakan dalam memodifikasi tepung cassava. Hasil penelitian Sinaga menunjukkan bahwa BAL yang digunakan belum secara optimal memodifikasi pati sagu. Hal ini disebabkan antara lain karena sifat tepung cassava berbeda dengan pati sagu sehingga penggunaan BAL yang sama tidak memberikan hasil pati termodifikasi yang sama baiknya.

Berdasarkan hal tersebut perlu dicari BAL yang mampu memodifikasi pati sagu sehingga pemanfataan pati sagu dalam pengolahan pangan dapat lebih luas lagi. Isolasi BAL dari industri pengolahan pati sagu diharapkan dapat menghasilkan BAL yang mampu memodifikasi pati sagu lebih baik dibandingkan dengan BAL yang biasa digunakan untuk memodifikasi tepung cassava. Tujuan penelitian adalah mengkarakterisasi bakteri asam laktat amilolitik dari industri pengolahan pati sagu yang berasal Kabupaten Kepulauan Meranti.

\section{METODE PENELITIAN}

\section{Alat dan Bahan}

Bahan yang digunakan dalam penelitian adalah pati sagu basah dan limbah cair dari industri pengolahan pati sagu yang diperoleh dari Kabupaten Kepulauan Meranti Provinsi Riau. Sampel berupa pati sagu basah dan limbah cair diambil masing-masing satu botol yang berukuran $600 \mathrm{~mL}$. Sampel kemudian dianalisis nilai $\mathrm{pH}$ dan aromanya. Bahan kimia yang digunakan adalah media pertumbuhan mikrobia de Man Rogosa and Sharpe (MRS) broth dan agar (Merck.), akuades, kalsium karbonat $\left(\mathrm{CaCO}_{3}\right.$, natrium klorida $(\mathrm{NaCl})$ produksi Merck, alkohol, safranin, iodida $\left(\mathrm{I}_{2}\right)$, kalium iodida (KI), kristal violet, hidrogen peroksida, larutan lugol's iodine, indikator fenolftalein, kapas dan kertas pembungkus. Bahan untuk identifikasi yaitu kit API 50 CHL (API system, Biomerieux). Alat-alat yang digunakan dalam penelitian ini meliputi: laminar air flow (Elisa), vortex-mixer (Taiyo s-100), inkubator (Memmert), autoklaf (all American), timbangan digital (Shimadzu), mikropipet (Soccorex), $\mathrm{pH}$ meter (Loviband), dan sentrifus (Weston-s-mare).

\section{Tahapan Penelitian}

Penelitian dilakukan dalam 3 tahap, yaitu tahap pertama isolasi dan pemurnian isolat, kedua karakterisasi kemampuan amilolitik dan ketiga identifikasi bakteri asam laktat dari industri pengolahan pati sagu. Sebelum dilakukan isolasi bakteri asam laktat, dilakukan pengukuran nilai $\mathrm{pH}$ dan penilaian aroma pada sampel.

\section{Isolasi dan Pemurnian Isolat Bakteri Asam Laktat}

Sumber bakteri asam laktat adalah pati sagu basah dan limbah cair pengolahan pati sagu. Isolasi bakteri asam laktat dilakukan secara pour plate. Satu mililiter sampel dimasukkan ke dalam 9 mL larutan $0,85 \%$ garam fisiologis steril dan diaduk hingga tercampur merata. Kemudian dilakukan pengenceran hingga $10^{-5}$. Masing-masing pengenceran diambil $1 \mathrm{~mL}$ dan dimasukkan ke dalam cawan petri kermudian ditambahkan \pm $15 \mathrm{~mL}$ media MRS agar yang telah ditambah $0,2 \% \mathrm{CaCO}_{3}$. Setelah media MRS agar mengeras, cawan petri dimasukkan ke dalam inkubator pada suhu $37^{\circ} \mathrm{C}$ dan diinkubasi selama 48 jam. Koloni yang membentuk zona bening pada media MRS agar (diduga sebagai bakteri asam laktat) diambil dengan jarum ose dan diinokulasikan pada media yang sama dengan goresan (sreak plate), kemudian diinkubasi pada suhu $37{ }^{\circ} \mathrm{C}$ selama 48 jam. Metode goresan dilakukan berulangulang hingga diperoleh koloni dengan bentuk yang seragam 
dan terpisah. Isolat yang diperoleh ditumbuhkan pada media MRS broth dan selanjutnya $50 \mu \mathrm{L}$ isolat diinokulasikan ke dalam MRS agar sebagai stok kultur. Stok kultur disimpan didalam lemari pendingin.

\section{Karakterisasi Isolat Amilolitik}

Karakterisasi kemampuan amilolitik dari bakteri asam laktat mengacu pada Sarah dkk. (2009). Isolat yang diperoleh pada tahap pemurnian dan diduga sebagai bakteri asam laktat ditumbuhkan pada media MRS broth selama 24-48 jam, kemudian diinokulasikan pada media nutrient agar yang ditambah pati sebanyak $1 \%$ dan diinkubasi pada suhu 37 ${ }^{\circ} \mathrm{C}$ selama 24-48 jam. Selanjutnya larutan KI dan $\mathrm{I}_{2}(0,25 \%$ kristal iodin ditambahkan pada larutan $1 \%$ larutan kalium iodida) dituangkan di atas media yang telah diinokulasi isolat yang diduga BAL. Aktivitas amilase ditunjukkan dengan adanya zona bening di sekitar isolat dan besarnya zona bening diukur dengan jangka sorong.

\section{Identifikasi Bakteri Asam Laktat}

Untuk memastikan bahwa isolat yang didapat adalah bakteri asam laktat, maka dilakukan uji konfimasi yang meliputi pewarnaan Gram, uji katalase, uji produksi gas dari glukosa untuk menentukan tipe fermentasi dan morfologi sel. Pengujian mengacu pada Rahayu dan Margino (1997).

\section{Identifikasi dengan Kit API 50 CHL}

Penggunaan kit API 50 CHL bertujuan untuk mengetahui spesies bakteri asam laktat. Pekerjaan diawali dengan menyiapkan strip dan kotak inkubasi. Satu buah strip digunakan untuk identifikasi satu isolat dan strip ini terdiri dari 5 strip kecil yang masing-masing mengandung 10 cupule. Kotak inkubasi terdiri dari bagian bawah yang mempunyai 50 buah cekungan dan bagian atas/tutup. Akuades steril $( \pm 1 \mathrm{~mL})$ dimasukkan pada masing-masing cekungan yang terdapat kotak inkubasi bagian bawah kemudian strip diletakkan pada kotak inkubasi yang telah diisi akuades steril.

Pekerjaan selanjutnya adalah menyiapkan inokulum yang akan diuji. Dua ose inokulum yang telah ditumbuhkan selama 24 jam pada media MRS agar dimasukkan ke dalam larutan basal dan diaduk hingga inokulum terdispersi secara merata di dalam larutan basal. Inokulum yang telah diinokulasikan ke dalam larutan basal dimasukkan ke dalam 50 buah cupule yang terdapat pada strip dengan menggunakan pipet steril dan dihindari terbentuknya gelembung udara selama proses pemasukan suspensi ke dalam cupule. Setelah semua cupule terisi inokulum, bagian atas strip ditambah mineral oil hingga cupule penuh kemudian strip diletakkan pada kotak inkubasi dan ditutup. Kotak inkubasi dimasukkan ke dalam inkubator dengan suhu $37{ }^{\circ} \mathrm{C}$ dan dibiarkan selama
48 jam. Perubahan warna pada masing-masing cupule dicatat. Hasil dikatakan positif $(+)$ jika terjadi perubahan dari warna ungu menjadi kuning dan negatif (-) jika tidak terjadi perubahan warna. Hasil pencatatan kemudian dimasukkan ke dalam identification software untuk menentukan spesies dari isolat yang diuji.

\section{HASIL DAN PEMBAHASAN}

\section{Nilai pH dan Aroma Pati Sagu Basah dan Limbah Cair}

Sampel berupa pati sagu basah dan limbah cair dari pengolahan pati sagu yang berasal dari Kabupaten Kepulauan Meranti diukur $\mathrm{pH}$ dengan menggunakan $\mathrm{pH}$ meter dan selajutnya aroma dari sampel tersebut dinilai langsung oleh peneliti. Pengujian hanya dilakukan satu kali. Hasil pengujian menunjukkan bahwa nilai $\mathrm{pH}$ pati sagu basah dan limbah cair pengolahan pati sagu basah tergolong rendah dan beraroma asam. Data pengukuran nilai $\mathrm{pH}$ disajikan pada Tabel 1 .

Tabel 1 menunjukkan bahwa kedua sampel mempunyai $\mathrm{pH}$ yang rendah dan beraroma asam. Dalam proses pengolahan pati sagu terdapat tahap pengendapan pati, dan diduga pada tahap pengendapan yang memakan waktu 1 malam telah terjadi proses fermentasi spontan yang menyebabkan penurunan nilai $\mathrm{pH}$ pada pati dan pada air pengolahannya. Pati sagu mengandung amilosa yang dapat dimanfaatkan oleh beberapa mikroorganisme salah satunya oleh bakteri asam laktat. Putri dkk. (2012) menyatakan bahwa isolat Lactobacillus plantarum dan L. rhamnosus mampu tumbuh pada growol (makanan tradisional berbasis cassava) yang kaya akan pati.

Tabel 1 juga menunjukkan bahwa nilai $\mathrm{pH}$ pati sagu basah lebih rendah dibanding limbah cair pengolahan pati sagu. Hal ini membuktikan bahwa pati merupakan sumber nutrisi yang dapat dimanfaatkan oleh mikroorganisme yang selanjutnya akan dimetabolisme menjadi asam-asam organik. Pati sagu basah mengandung pati (amilum) jauh lebih banyak dibandingkan limbah cair. Pati inilah yang akan dijadikan sebagai sumber nutrisi oleh bakteri asam laktat untuk tumbuh dan berkembag biak. Pati sagu akan dimetabolisme lebih lanjut menjadi asam organik terutama asam laktat

\section{Isolasi dan Pemurnian Isolat}

Tabel 1. Nilai $\mathrm{pH}$ dan aroma pati sagu basah dan limbah cair dari pengolahan pati sagu

\begin{tabular}{lcc}
\hline Sampel & Nilai $\mathrm{pH}$ & Aroma \\
\hline Pati sagu basah & 3,78 & Asam \\
Limbah cair pengolahan pati sagu & 4,63 & Asam \\
\hline
\end{tabular}


Setelah dilakukan isolasi mikroba dari pati sagu basah dan limbah cair pengolahan pati sagu, dilakukan pemurnian. Hasil isolasi dan pemurnian mendapatkan 39 isolat, 36 isolat diantaranya menghasilkan zona bening pada media MRS Agar yang ditambah $\mathrm{CaCO}_{3}$. Zona bening di sekitar koloni terbentuk sebagai akibat penetralan oleh $\mathrm{CaCO}_{3}$ terhadap asam yang dihasilkan oleh bakteri asam laktat (Nurmalinda dkk., 2014).

Adanya zona bening pada media MRS Agar yang ditambah $\mathrm{CaCO}_{3}$ mengindikasikan adanya produksi asam dari isolat tersebut. Isolat yang menghasilkan asam diduga sebagai bakteri asam laktat. Beberapa isolat yang menghasilkan asam disajikan pada Gambar 1.

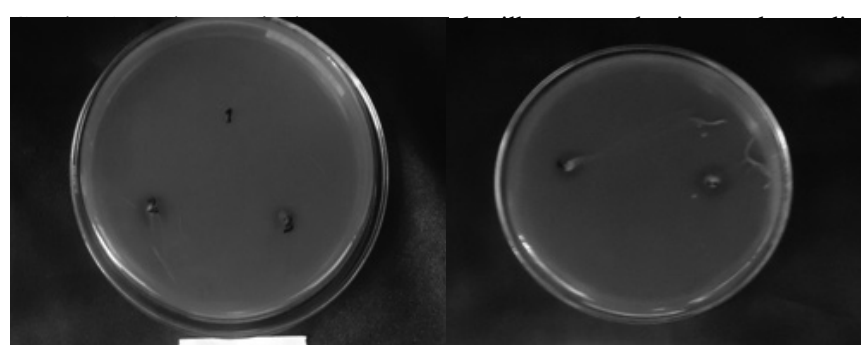

Gambar 1 menunjukkan bahwa kemampuan isolat dalam memproduksi asam tidak sama persis, hal ini terlihat dari luas atau tidaknya zona bening yang ada di sekitar isolat. Semakin luas zona bening di sekitar isolat, mengindikasikan semakin besar kemampuan isolat memproduksi asam. Yusmarini dkk. (2009) melaporkan bahwa isolat Lactobacillus plantarum 1 R.1.3.2 yang diisolasi dari susu kedelai yang terfermentasi spontan, menghasilkan asam lebih tinggi dibandingkan L. plantarum 1 R.11.1.2. Bordignon dkk. (2004) menyatakan bahwa Lactococcus lactis subsp. lactis JCM 5805 mempunyai kemampuan menghasilkan asam lebih tinggi dibandingkan Bifidobacterium adolescentis JCM 1275. Hal ini ditandai dengan semakin rendahnya $\mathrm{pH}$ media yang diinokulasi oleh Lactococcus lactis subsp. lactis JCM 5805.

\section{Karakterisasi Isolat Amilolitik}

Karakterisasi isolat yang bersifat amilolitik bertujuan untuk mendapatkan bakteri asam laktat yang mampu menghasilkan enzim amilase. Aktivitas amilolitik dari bakteri asam laktat diharapkan dapat memodifikasi pati sagu dengan baik. Enzim amilase yang dihasilkan oleh isolat merupakan enzim ekstraseluler yang diproduksi di dalam sel dan kemudian dikeluarkan dari sel ke substrat yang ada di sekitarnya. Enzim amilase yang diproduksi selanjutnya akan menghidrolisis amilosa yang terdapat pada media dan
Tabel 2. Hasil pengukuran zona bening pada media NA yang ditambah pati

\begin{tabular}{lc}
\hline \multicolumn{1}{c}{ Kode isolat } & Diameter zona bening $(\mathrm{cm})$ \\
\hline RN1.2313 & 0,29 \\
RN2.1211 & 0,38 \\
RN2.12112 & 0,82 \\
RN1. 23121 & 0,18 \\
RN2.211 & 0,39 \\
RN2.212 & 0,62 \\
RN1.52 & 0,34 \\
RN1. 42 & 0,22 \\
RN2.53 & 0,52 \\
\hline
\end{tabular}

akan terlihat adanya zona bening di sekitar isolat. Reddy dkk. (2003) menyatakan bahwa enzim amilase akan memutus ikatan glikosida yang terdapat pada molekul amilum. Hasil hidrolisis berupa maltosa, glukosa dan dekstrin. Molekulmolekul sederhana tersebut tidak akan memberikan warna biru tua saat ditetesi dengan larutan KI sedangkan amilum yang tidak terhidrolisis akan memberikan warna biru tua. Hasil pengukuran zona bening disajikan pada Tabel 2 .

Zona bening yang dihasilkan isolat pada media yang mengandung pati menunjukkan kemampuan isolat dalam menghasilkan enzim amilase. Semakin besar zona bening di sekitar isolat berarti semakin besar pula kemampuan isolat tersebut dalam menghasilkan enzim amilase. Tabel 2 menunjukkan bahwa isolat RN2.12112 dan isolat RN2.212 secara kualitatifmempunyai kemampuan amilolitik lebih besar dibandingkan isolat lainnya. Petrova dkk. (2010) menyatakan bahwa isolat $L$. pentosus N3, mempunyai aktivitas amilolitik lebih besar dibandingkan isolat L. plantarum Bom 816. Isolat L. pentosus N3 dan L.plantarum Bom 816 merupakan isolat yang diisolasi dari minuman fermentasi tradisional berbasis cereal. Aktivitas amilolitik dibutuhkan untuk memodifikasi berbagai pati diantaranya pati sagu. Sobowale dkk. (2007) memanfaatkan L. plantarum strains SL14 dan SL 19 untuk memodifikasi pati cassava. Akan tetapi isolat tersebut tidak memberikan efek yang signifikan terhadap perubahan sifat kimia pati cassava. Putri dkk. (2012) menyatakan bahwa isolat L. plantarum dan L. rhamnosus mampu memanfaatkan pati yang terdapat pada growol (makanan tradisional berbasis cassava).

\section{Identifikasi Bakteri Asam Laktat}

Isolat yang menghasilkan asam yang ditandai dengan adanya zona jernih pada media MRS agar dan mempunyai aktivitas amilolitik, kemudian diidentifikasi lebih lanjut yang meliputi pewarnaan Gram, bentuk sel, uji katalase dan 
Tabel 3. Karakteristik isolat yang diisolasi dari industri pengolahan pati sagu

\begin{tabular}{ll}
\hline \multicolumn{1}{c}{ Kode isolat } & \multicolumn{1}{c}{ Tipe sel } \\
\hline RN1. 2313 & Monobasil, diplobasil \\
RN2.1211 & Monobasil \\
RN2.12112 & Monobasil, diplobasil \\
RN1.23121 & Monobasil \\
RN2.211 & Monobasil, diplobasil \\
RN2.212 & Monobasil, diplobasil \\
RN1. 52 & Monobasil, diplobasil \\
RN1.42 & Monobasil, diplobasil \\
RN2.53 & Monobasil, diplobasil \\
\hline
\end{tabular}

produksi gas dari glukosa. Tipe sel dari masing-masing isolat disajikan pada Tabel 3.

Data pada Tabel 3 menunjukkan bahwa dari 9 isolat yang diduga BAL, 7 isolat memiliki tipe sel monobasil dan diplobasil sedangkan 2 sel memiliki tipe sel monobasil. Kusumaningrum, dkk. (2015) melaporkan bahwa 9 isolat memiliki sel berbentuk basil pendek dan merupakan bakteri Gram positif, katalase negatif serta 5 isolat memproduksi gas dan 4 isolat tidak menghasilkan gas dari glukosa. Hasil penelitian Yusmarini dkk. (2009) juga menunjukkan bahwa isolat R.1.3.2 dan R11.1.2 yang diperoleh dari susu kedelai yang terfermentasi spontan berbentuk batang pendek dan ukurannya lebih pendek dibanding L. acidophilus. Lima isolat bersifat heterofermetatif (menghasilkan gas) dan empat isolat bersifat homofermentatif (tidak menghasilkan gas). Wood (1992) menyatakan bahwa bakteri asam laktat adalah bakteri yang menghasilkan asam pada metabolisme karbohidratnya, tergolong Gram positif, berbentuk bulat atau batang, katalase negatif dan pada umumnya bersifat tidak motil, tetapi ada beberapa yag bersifat motil. Identifikasi lebih lanjut dibutuhkan untuk mengetahui spesies dari isolat yang diperoleh. Identifikasi dilakukan dengan menggunakan kit API 50 CHL yang merupakan pengujian terhadap kemampuan isolat untuk memfermentasi berbagai jenis karbohidrat. Hasil identifikasi dengan menggunakan Kit API 50 CHL disajikan pada Tabel 4.

Dari sembilan isolat yang diidentifikasi terlihat bahwa isolat hasil isolasi dari industri pengolahan pati sagu didominasi oleh spesies L. plantarum 1. Isolat RN2.1211 dan RN2.211 dan RN2.212 kemungkinan kurang murni sehingga hasil pengukuran dengan Kit API CHL 50 menjadi tidak akurat. Rahayu (2003) menyatakan bahwa salah satu bakteri asam laktat yang tumbuh dominan pada makanan tradisional Indonesia terutama makanan fermentasi adalah L. plantarum.
Tabel 4. Hasil identifikasi isolat dengan Kit API 50 CHL

\begin{tabular}{|c|c|c|}
\hline Kode isolat & Hasil identifikasi & Tingkat akurasi \\
\hline RN1. 2313 & $\begin{array}{l}\text { Lactobacillus } \\
\text { plantarum } 1\end{array}$ & $\begin{array}{l}99,9 \% \text { very good } \\
\text { identification }\end{array}$ \\
\hline RN2. 1211 & $\begin{array}{l}\text { Lactobacillus } \\
\text { plantarum } 1\end{array}$ & Anacceptable profile \\
\hline RN2. 12112 & $\begin{array}{l}\text { Lactobacillus } \\
\text { plantarum } 1\end{array}$ & $\begin{array}{l}99,9 \% \text { very good } \\
\text { identification }\end{array}$ \\
\hline RN1. 23121 & $\begin{array}{l}\text { Lactobacillus } \\
\text { plantarum } 1\end{array}$ & $\begin{array}{l}99,9 \% \text { exellent } \\
\text { identification }\end{array}$ \\
\hline RN2. 211 & $\begin{array}{l}\text { Lactobacillus } \\
\text { rhamnosus }\end{array}$ & Anacceptable profile \\
\hline RN2. 212 & $\begin{array}{l}\text { Lactobacillus } \\
\text { rhamnosus }\end{array}$ & Anacceptable profile \\
\hline RN1. 52 & $\begin{array}{l}\text { Lactobacillus } \\
\text { plantarum } 1\end{array}$ & $\begin{array}{l}99,9 \% \text { very good } \\
\text { identification }\end{array}$ \\
\hline RN1. 42 & $\begin{array}{l}\text { Lactobacillus } \\
\text { plantarum } 1\end{array}$ & $\begin{array}{l}99,9 \% \text { very good } \\
\text { identification }\end{array}$ \\
\hline RN2.53 & $\begin{array}{l}\text { Lactobacillus } \\
\text { plantarum } 1\end{array}$ & $\begin{array}{l}99,9 \% \text { very good } \\
\text { identification }\end{array}$ \\
\hline
\end{tabular}

Hasil penelitian Chahrour dkk. (2013) menunjukkan bahwa isolat bakteri asam laktat dari proses pembuatan silase sorghum didominasi oleh L. manihotivorans sedangkan Putri dkk. (2012) menyatakan bahwa L. plantarum dan L. rhamnosus mendominasi selama fermentasi growol. Perbedaan jenis bakteri asam laktat amilolitik hasil identifikasi ditentukan oleh beberapa faktor salah satunya adalah substrat atau media tumbuh. Jenis dan kondisi media menjadi penentu jenis dan kemampuan isolat bakteri asam laktat dalam memfermentasi pati sebagai substrat bagi pertumbuhannya. Hal inilah yang menyebabkan beragamnya jenis isolat amilolitik yang diisolasi dari jenis media yang berbeda.

\section{KESIMPULAN}

Penelitian menghasilkan sembilan isolat yang bersifat amilolitik. Hasil identifikasi secara morfologi menunjukkan bahwa kesembilan isolat tersebut termasuk kelompok bakteri Gram positif, berbentuk batang pendek, katalase negatif, dan lima isolat bersifat heterofermentatif sedangkan empat isolat bersifat homofermentatif. Kemampuan isolat untuk menghasilkan amilase bervariasi dan isolat RN2.12112 mempunyai kemampuan amilolitik lebih tinggi dibanding isolat lainnya. Hasil identifikasi menunjukkan bahwa dari sembilan isolat yang diidentifikasi didominasi oleh Lactobacillus plantarum 1. 


\section{UCAPAN TERIMA KASIH}

Ucapan terima kasih disampaikan kepada DRPM Kemenristek dan Dikti atas dukungan pendanaannya melalui skim Hibah Bersaing Tahun Anggaran 2014-2015 dan kepada Kusumaningrum yang ikut terlibat dalam pelaksanaan payung penelitian dalam rangka penyelesaian tugas akhirnya.

\section{DAFTAR PUSTAKA}

Agati, V.J.P., Guyot, J., Morlon-Guyot, P., Talamond dan Hounhouigan, D.J.(1998). Isolation and characterization of new amylolytic strains of Lactobacillus fermentum from fermented maize doughs (mawe and ogi) from Benin. Journal of Applied Microbiology 85: 512-520.

Armanto, R. dan Nurasih, A.S. (2008). Kajian konsentrasi bakteri asam laktat dan lama fermentasi pada pembuatan tepung pati singkong asam. Agritech 28(3): 97-101.

Bordignon, J.R., Nakahara, K., Yoshihashi, T. dan Nikkuni, S. (2004). Hydrolysis of isoflavone and consumption of oligosacharides during lactic acid fermentation of soybean milk. Japan Agricultural Research Quarterly 38(4): 259-265.

Chahrour, W., Merzouk, Y., Henni, J.E., Haddaji, M. dan Kihal, M. (2013). Screening and identification of lactic acid bacteria isolated from sorghum silage processes in west Algeria. African Journal of Biotechnology 12(14): 1703-1709.

Jenie, B.S.L., Putra R.P. dan Kusnandar, F. (2012). Fermentasi kultur campuran bakteri asam laktat dan Pemanasan otoklaf dalam meningkatkan kadar pati resisten dan sifat fungsional tepung pisang tanduk (Musa paradisiacal formatypica). Jurnal Pascapanen 9(1): 18-26.

Nurmalinda, A., Periadnadi dan Nurmiati (2013). Isolasi dan karakterisasi parsial bakteri indigenous pemfermentasi dari buah durian (Durio zibethinus Murr.). Jurnal Biologi Universitas Andalas 2(1): 8-13.

Petrova, P., Emanuilova, M. dan Petrov, K. (2010). Amylolytic Lactobacillus strains from Bulgarian Fermented Beverage Boza. Verlag der Zeitschrift für Naturforschung, Tübingen. 218-224.

Putri, W.D.R., Haryadi, Marseno, D.W. dan Cahyanto, M.N. (2012). Isolasi dan karakterisasi bakteri asam laktat amilolitik selama fermentasi growol, makanan tradisional Indonesia. Jurnal Teknologi Pertanian 13(1): 52-60.
Rahayu, E.S. dan Margino, S. (1997). Bakteri asam laktat: isolasi dan identifikasi. Materi Workshop, diselenggarakan oleh PAU Pangan Gizi. Universitas Gadjah Mada 13-14 Juni 1997. Yogyakarta

Rahayu, E.S. (2003). Lactic acid bacteria in fermented food Indonesian origin. Agritech 23(2): 75-84.

Reddy, N.S., Nammagadda, A., Rao,K.R.S. dan Sambusiva. (2003). An Overview of the microbilogy $\alpha$-amilase family. African Journal Biotechnology 2: 645-648.

Sarah, Putra S.R. dan Putro, H.S. (2009). Isolasi $\alpha$-Amilase Termostabil dari Bakteri Termofilik Bacillus stearitermophilus. Skripsi Jurusan Kimia Fakultas Matematika dan Ilmu Pengetahuan Alam. Institut Tenologi Sepuluh November. Surabaya.

Sinaga, P. (2012). Pembuatan modified sago starch secara fermentasi menggunakan bakteri asam laktat. Skripsi. Fakultas Pertanian Universitas Riau. Pekanbaru.

Sobowale, A.O., Olurin, T.O. dan Oyewole, O.B. (2007). Effect of lactic acid bacteria starter culture fermentation of cassava on chemical and sensory characteristics of fufu flour. African Journal of Biotechnology 6(16): 1954-1958.

Songré-Ouattara, L.T., Mouquet-Rivier, C., Icard-Vernière, C., Humblot, C., Diawara, B. dan Guyot, J.P. (2008). Enzyme activities of lactic acid bacteria from a pearl millet fermentedgruel (ben-saalga) of functional interest in nutrition. International Journal of Food Microbiology 128: 395-400.

Wood, B.J.B. (1992). The Lactic Acid Bacteria in Health and Deseases. Blackie Academic and Professional, London.

Yusmarini, Indrati, R., Utami, T. dan Marsono, Y. (2009). Isolasi dan identifikasi bakteri asam laktat proteolitik dari susu kedelai yang terfermentasi spontan. Jurnal Natur Indonesia 2(1): 28-33. 